\title{
BIOLOGICAL AND ECONOMICAL MERITS OF INCORPORATING AZZAWI DATES IN RATIONS OF BARKI EWES UNDER DESERT CONDITIONS IN EGYPT
}

\author{
Mona I. Mohammady, A.H. Hammam and K.Z. Kewan \\ Division of Animal Production and Poultry, Desert Research Center, 1 Matahaf El Mataria St., P.O. Box \\ 11753, Mataria, Cairo, Egypt \\ *corresponding author email: $\underline{\text { monamohammady@hotmail.com }}$
}

\section{SUMMARY}

This study was conducted to evaluate the effects of feeding non-conventional source of energy Azzawi date (non -edible date) on biological performance of Barki ewes and assess the economic returns from mid pregnancy period up to weaning age. Thirty Barki ewes were used with average initial live body weight of 42.4 $\pm 3 \mathrm{~kg}$ and ranging between $2-5$ years. Ewes were randomly distributed into three equal groups (G1, G2 and G3). Ewes of G1 fed traditional diet formulated of concentrate feed mixture (CFM) free of Azzawi date and served as control group, while ewes of G2, fed CFM with partial replacement (50\%) of corn grain. Ewes of G3 fed CFM with totally replacement (100\%) of corn grain by Azzawi date. The results showed that, inclusion of Azzawi date in the diet did not affect negatively live body weight changes of ewes and weight of fetus throughout the pregnancy period. Group 3 achieved the highest estimates and harvest more number of weaned lambs (78\%) and lowest mortality rate $(22 \%)$ but the differences were not significant. The experimental diets had no significant effect on birth weight, weaning weight, and average daily gain. Lambs born of G1 were lighter in birth weight $(3.53 \mathrm{~kg})$ than $G 2$ and $G 3(3.88 \mathrm{~kg} \& 3.71 \mathrm{~kg}$, respectively), but faster in growth rate $(0.145 \mathrm{~kg} /$ day) and heavier weaning weight $(16.72 \mathrm{~kg})$. Relative economic indicators revealed that, G3 had the highest reduction in total feed costs and scored $-15.22 \%$, while G2, was intermediate and scored -7.98\% less than the control group (G1). G3 achieved the lowest feed costs to produce one kilogram of weaned lambs, while G1 was the highest (LE 27.38 vs. LE 31.55).

It could be concluded that, incorporating Azzawi date with ewes diets from mid pregnancy until weaning age did not enhance ewe or lamb production traits but minimized the feed costs of ewes during the studied experimental period.

\section{Keywords: Barki sheep, Azzawi date, production, reproduction, economical, biological}

\section{INTRODUCTION}

In order to bridge the shortage of feeding and reduce feeding costs, alternative cheap feedstuffs resources need more investigations as a sustainable strategy in sheep farming systems. In this respect, non-edible date represents energy-rich alternative ingredient that can be locally exploited in Egypt as a replacer to the more conventional corn grain in sheep diets. A few research trails were conducted to investigate the impact of using alternative feed resources on biological performance of Barki sheep. However, the effect of feeding Azzawi date on reproductive performance has not yet been investigated. For this reason, the present study represents one of the research trials series done by the authors concerning the effect of replacing corn grain of concentrate feed mixture by different levels of Azzawi date on biological performance of Barki ewes in addition to assess the economical efficiency during different production periods.

\section{MATERIALS AND METHODS}

\section{Study location:}

This study was carried out in 2010 at Maryout Research Station, belonging to Desert Research
Center. This station is located in the North Western Coast of Egypt, $180 \mathrm{~km}$ from Cairo.

\section{Experimental diets}

Azzawi date is a non-edible kind of date for human consumption and was collected in its whole form from Siwa Oasis and incorporated into feeding diets as alternative cheap source of energy-rich nutrients. The current study used three experimental diets aiming at replacing partially or totally corn grain in a convential concentrate feed mixture (CFM) by different levels of Azzawi date $(0 \%, 50 \%$ and $100 \%)$. The experimental rations were formulated to cover nutrients requirements according to recommended level of NRC (1985). The first experimental diet, CFM was free of Azzawi date $(0 \%)$ and served as a control diet (C). While, in the second experimental diet, Azzawi date replaced 50\% of corn grain in the concentrate feed mixture. In the third experimental diet, Azzawi date replaced $100 \%$ of corn grain in CFM. Concentrate feed mixture used in formulating experimental diets was composed of $50 \%$ undecorticated cotton seed cake, $18 \%$ wheat bran, $15 \%$ yellow maize, $11 \%$ rice polish, $3 \%$ molasses, $2 \%$ limestone and $1 \%$ common salt. Chemical composition of corn grain and Azzawi date are presented in Table (1) as cited by Khattab et al. (2012). 


\section{Experimental design:}

A total number of 30 multiparous and nulliparous Barki ewes with average initial live body weight of $42.4 \pm 3 \mathrm{~kg}$ and aged 2-5 years were used in the present study. Experimental ewes were randomly distributed into three equal groups (10 each) balanced for age and live body weight. Each group was housed in separated shaded pen. All ewes were fed a traditional rations from mating until mid pregnancy period. The treatment groups received the proposed experimental diets until the end of lactation period.

From mid pregnancy ewes of group 1 (G1) were fed traditional diet formulated of CFM free of Azzawi date and served as control group, while ewes of group $2(\mathrm{G} 2)$, fed CFM with partial replacement $(50 \%)$ of corn grain. Meanwhile, ewes of group 3 (G3) fed CFM with total replacement (100\%) of corn grain by Azzawi date. The experiment period lasted for 177 days.

\section{Management practices:}

The experimental ewes were naturally mated once a year at autumn season from $15^{\text {th }}$ of September and the breeding season lasted for 34 days (2 estrus cycles). Ewes in each group were assigned with a fertile breeding ram. Rams' briskets were colored with different colored grease fortnightly, and mating pens were checked daily for colored ewes. Rations offered to the experimental ewes consisted of $50 \%$ Alfalfa hay and $50 \%$ concentrate feed mixture (as fed). Half to one $\mathrm{kg}$ CFM per ewe was offered daily according to physiological statues of the experimental ewes. Throughout the experiment period, ewes in each group were individually weighed before morning feeding at the beginning of the study (initial body weight) and monthly thereafter. Changes of live body weight were recorded throughout the study. Average dry matter intake per ewe of each group was calculated during the experimental period. After parturition, newborn lambs were weighed at birth and biweekly thereafter up to weaning age (90 days). Table (2) shows the chemical composition of the experimental diets and alfalfa hay offered to ewes of G1, G2 and G3 as suggested by Mohammady et al. (2013).

Table 1. Chemical composition and fiber fractionations (\%) of corn grain and Azzawi date

\begin{tabular}{lcc}
\hline Component & Corn grain & Azzawi date \\
\hline Crude protein & 8.50 & 7.40 \\
Crude fiber & 2.54 & 7.52 \\
Ether extract & 4.16 & 3.83 \\
Nitrogen free extract & 83.19 & 76.92 \\
Ash & 1.58 & 4.31 \\
Neutral detergent fiber & 21.41 & 18.83 \\
Acid detergent fiber & 5.36 & 18.28 \\
Sugar & 8.28 & 46.95 \\
\hline
\end{tabular}

Table 2. Chemical composition (\%) of concentrate fed mixture and Alfalfa hay of the experimental diets (on DM basis)

\begin{tabular}{lcccc}
\hline \multirow{2}{*}{ Item } & \multicolumn{3}{c}{ Experimental diets } & Alfalfa hay \\
\cline { 2 - 4 } & $\mathbf{G 1}$ & $\mathbf{G 2}$ & $\mathbf{G 3}$ & 88.39 \\
\hline Dry matter & 89.49 & 88.52 & 89.53 & 90.78 \\
Organic matter & 94.44 & 90.69 & 89.94 & 16.05 \\
Crude protein & 16.66 & 16.94 & 16.89 & 2.28 \\
Ether extract & 3.77 & 3.64 & 3.54 & 27.35 \\
Crude fiber & 6.71 & 8.01 & 9.35 & 45.10 \\
Nitrogen free extract & 67.30 & 62.10 & 60.16 & 9.22 \\
Ash & 5.56 & 9.31 & 10.06 & \\
\hline
\end{tabular}

G1; ewes fed a diet free of Azzawi date (Control), G2; ewes fed a diet contains 50\% Azzawi date, and G3; ewes fed a diet contains $100 \%$ Azzawi date.

\section{Biological criteria:}

Reproductive evaluation in terms of conception rate, lambing rate (expressed as per ewe joined), average litter size \%, lambing \% (expressed as per ewe joined), weaning $\%$ and mortality rate (from birth to weaning) in addition to, kilograms weaned per ewe joined were estimated. Productive traits: birth weight, weaning weight and average daily gain were recorded. Daily feed intake per ewe as dry matter (DM) was estimated and adjusted for each group according to their reproduction stages, i.e. pregnancy and lactation. Feed conversion ratio expressed as number of kilograms dry matter intake (DMI) to produce one $\mathrm{kg}$ of weaned lambs was calculated.

\section{Economical evaluation:}

To facilitate comparison among the treatment groups, feed costs needed to produce one kilogram of weaned lambs and benefit/cost ratio (ratio of monetary value of weaned lambs to value of feed costs) were used as an indicators of the relative profitability of the three experimental diets. Variable costs included feed costs only, while revenues included the monetary value generated from selling 
lambs weaned from each group. Current farm gate prices in Egyptian pound of Alfalfa hay (LE 1600/ton), CFM (LE 2000/ton), Azzawi date (LE1000/ton) and marketed weaned lambs were considered (LE 35/kg).

\section{Statistical analysis:}

Data were statistically analyzed using the General Linear Model (GLM) procedures described by SAS (2004), and applying the following model:

$$
\mathrm{Y}_{\mathrm{ij}}=\mu+\mathrm{d}_{\mathrm{i}}+\mathrm{e}_{\mathrm{ij}}
$$

Where:

$\mathrm{Y}_{\mathrm{ij}}=$ the observation,

$\mu=$ the overall mean,

$d_{j}=$ the effect due to $i^{\text {th }}$ experimental diets, $i=1,2,3$, where, 1= CFM free of Azzawi date, 2= GFM contains $50 \%$ of Azzawi date, 3= CFM contains $100 \%$ of Azzawi date

$\mathrm{e}_{\mathrm{ij}}=$ random error associated with the $\mathrm{ij}^{\text {th }}$ observation. Differences among treatments were tested according to Duncan's new multiple ranges test (Duncan, 1955).

Table 3. Live body weight changes $(\mathrm{kg})(\mathrm{X} \pm \mathrm{S}$.E) of ewes during the experimental period

\begin{tabular}{lccc}
\hline Average body weight & G1 & G2 & G3 \\
\hline Initial & $43.0 \pm 1.80$ & $42.6 \pm 1.64$ & $41.6 \pm 2.18$ \\
At mid pregnancy (MP) & $45.0 \pm 1.81$ & $45.0 \pm 1.64$ & $43.0 \pm 2.35$ \\
At the end of pregnancy before & $47.6 \pm 1.49$ & $46.3 \pm 1.38$ & $46.6 \pm 2.59$ \\
lambing (EP) & 4.6 & 3.7 & 5.0 \\
Weight Loss after lambing & $42.1 \pm 1.70$ & $42.5 \pm 1.58$ & $41.5 \pm 2.02$ \\
\hline At the end of lactation (EL) & &
\end{tabular}

G1; ewes fed a diet free of Azzawi date (Control), G2; ewes fed a diet contains 50\% Azzawi date, and G3; ewes fed a diet contains $100 \%$ Azzawi date.

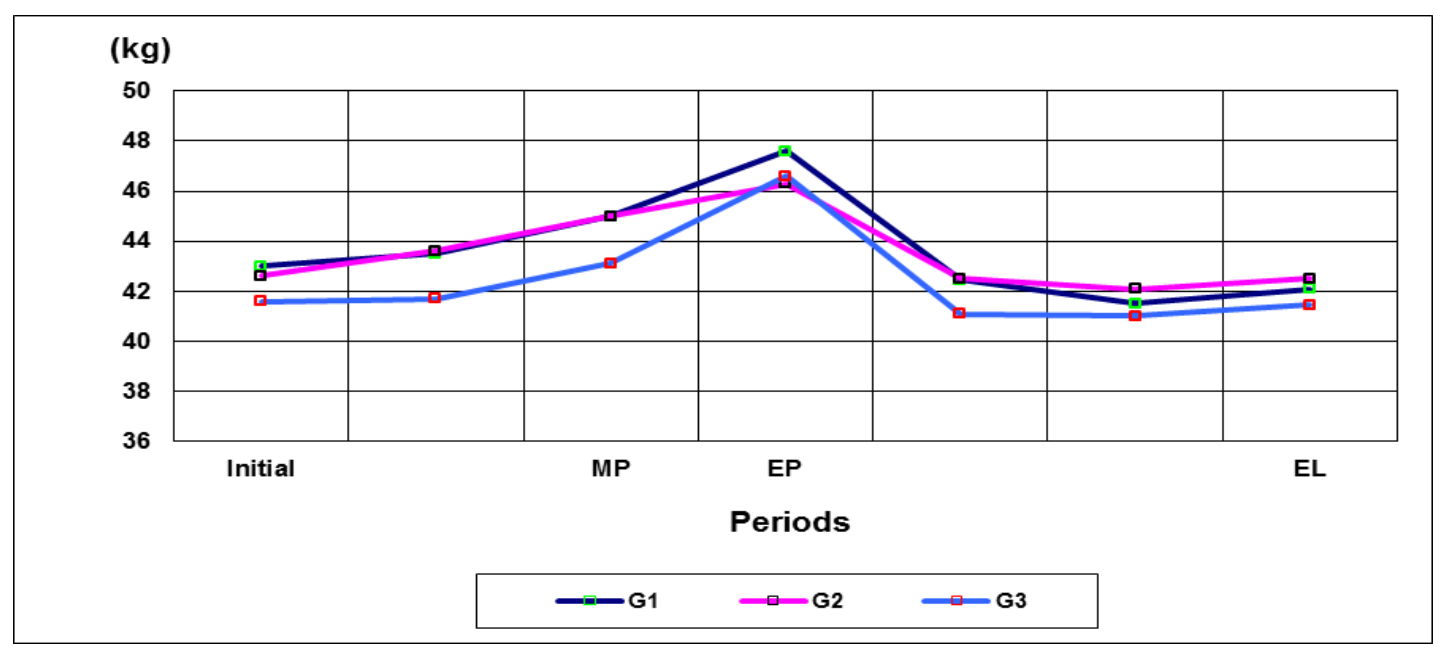

Figure 1. Changes of ewes live body weight through the experimental period

\section{Reproductive performance of ewes}

The obtained results (Table 4) revealed that, G1 was higher in conception rate $(100 \%)$ than $\mathrm{G} 2$, and G3, of $90 \%$ and $90 \%$, respectively, but the differences were not significant. These results are in agreement with Rekik et al. (2008) who found no significant differences in conception rates of D'Man ewes fed $25 \%, 50 \%$ and $75 \%$ of wasted dates. The obtained conception rates are higher than those previously reported for Barki sheep by, Mohammady (1999) (82.9\%) and Abdel Aziz (1983) (82.2\%). In this context, the current results showed that, lambing rate were $100 \%, 90 \%$ and $90 \%$ for G1, G2 and G3,

\section{RESULTS AND DISCUSSION}

\section{Live body weight changes of ewes}

No significant differences were found among ewes body weight. Results indicated that, such ewes of the present study were well managed. This might indicate that incorporation of Azzawi date, whether partially or totally did not have negative biological effects on growth of the embryo or dam. This may be attributed to similarity of crude protein \% in Azzawi date and corn grain (Table 1).

The current results are confirmed by the results of Rekik et al. (2008) who found no significant differences in live body weight variations among D' Man ewes fed on different levels of date $(25 \%$ and $50 \%$ ). The present study showed that, most of the weight loses occurred during the first month after the parturition, but thereafter, live body weight of ewes remained nearly constant in all treatment groups (Fig. $1)$. 
$(\mathrm{P}<0.05)$ compared with the other two levels $(25 \%$ and $50 \%$ ). 
Table 4. Reproductive performance of Barki ewes fed on different diets of Azzawi date

\begin{tabular}{lccc}
\hline Parameters & G1 & G2 & G3 \\
\hline No. of ewes joined & 10 & 10 & 10 \\
No. of ewes lambed & 10 & 9 & 9 \\
No. of lambs born alive & 11 & 9 & 9 \\
No. of lambs weaned & 7 & 6 & 7 \\
Conception rate, $(\%)$ & 100 & 90 & 90 \\
Lambing rate, $(\%)$ & 100 & 90 & 90 \\
Average litter size, $(\%)$ & 110 & 100 & 100 \\
Lambing percentage, $(\%)$ & 110 & 90 & 90 \\
Lambs weaned, $(\%)$ & 64 & 67 & 78 \\
Mortality rate (Birth- weaning), $(\%)$ & 36 & 33 & 22 \\
Kg of lambs weaned/ ewe joined, $(\mathbf{k g})$ & 11.70 & 9.72 & 11.34 \\
\hline
\end{tabular}

G1; ewes fed a diet free of Azzawi date (Control), G2; ewes fed a diet contains 50\% Azzawi date, and G3; ewes fed a diet contains $100 \%$ Azzawi date.

\section{Productive performance of lambs}

Concerning the effects of incorporation of Azzawi dates in rations of Barki ewes on their lambs growth rates, no significant differences existed in birth weight, weaning weight or average daily gain among the studied groups (Table 5). Least squares means and standard errors of birth weight, weaning weight and average daily gain as affected by experimental diets are presented in Table (5). The overall mean of birth weight $(3.67 \mathrm{~kg})$, is lower than that estimated by Mohammady (1999) (3.75 kg) and higher than estimated by Ahmed et al. (1992) (2.92 $\mathrm{kg})$. Also, the overall mean of weaning weight (16.42 $\mathrm{kg}$ ) is close to that reported by Mohammady (1999) (16.47 kg), and higher than Ahmed et al. (1992) $(14.1 \mathrm{~kg})$ for Barki sheep, but lower than that recorded by Younis et al. (1984) $(19.9 \mathrm{~kg})$ of the same breed. The overall mean of average daily gain was similar to that estimated by Mohammady (1999) of $140 \mathrm{~g} /$ day for Barki growing lambs.
However, the recent results indicate that, there are slight differences in estimates of birth weight, weaning weight and average daily gain among the control group (G1) and the other two treatment groups ( G2 and G3). Interestingly, the lambs of control group (G1) has the lowest birth weight comparing with G2 and G3 (3.53 kg vs. $3.88 \mathrm{~kg}$, and $3.71 \mathrm{~kg}$, respectively), but achieved the heaviest weaning weight $(16.72 \mathrm{~kg} v s .16 .2 \mathrm{~kg}$ and $16.34 \mathrm{~kg}$, respectively). In the same time, G1 scored the highest average daily gain than the other two treatment groups G2 and G3 (0.145 kg, vs. $0.137 \mathrm{~kg}$, and 0.139 $\mathrm{kg}$, respectively), but the differences were not significant. Lambs of control group (G1) tended to grow faster and performed higher weaning weight as compared to the other two groups, it could be due to the higher metabolic energy intakes and protein content of G1 in comparison with G2 and G3 (Khattab et al., 2012).

Table 5. Least squares means $\pm \mathrm{SE}$ for birth weight, weaning weight and average daily gain $(\mathrm{kg})$ of lambs under the experimental diets

\begin{tabular}{|c|c|c|c|c|}
\hline \multirow{2}{*}{ Traits } & \multirow{2}{*}{ Overall mean } & G1 & G2 & G3 \\
\hline & & SE & SE & SE \\
\hline Birth weight & $3.67 \pm 0.12$ & $3.53 \pm 0.02$ & $3.88 \pm 0.02$ & $3.71 \pm 0.01$ \\
\hline Weaning weight & $16.42 \pm 0.42$ & $16.72 \pm 0.04$ & $16.2 \pm 0.05$ & $16.34 \pm 1.04$ \\
\hline Average daily gain & $0.140 \pm 0.004$ & $0.145 \pm 0.005$ & $0.137 \pm 0.007$ & $0.139 \pm 0.009$ \\
\hline
\end{tabular}

G1; ewes fed a diet free of Azzawi date (Control), G2; ewes fed a diet contains 50\% Azzawi date, and G3; ewes fed a diet contains 100\% Azzawi date.

\section{Feed intake}

Results presented in Table (6) show feed consumption in terms of dry matter intake (DMI) per ewe throughout the experimental period (177 days). During the mid pregnancy period (77 days), results declared that each ewe consumed average dry matter of $0.865 \mathrm{~kg}$ per day for all treatment groups representing $2.1 \%$ of their average live body weight $(42.4 \mathrm{~kg})$. This amount of feed covered their maintenance requirements judging their live body weight gain during such period. Corresponding values over late pregnancy and at lactation period which extended 100 days, DMI were $1.69 \mathrm{~kg}, 1.67 \mathrm{~kg}$ and $1.695 \mathrm{~kg}$ for G1, G2 and G3, respectively, representing about $3.5 \%$ of their live body weight.
Results indicated that DMI tended to increase as expected from mid pregnancy period up to the end of lactation due to the changes of their physiological status to cover the requirement of the growing foetus before and after parturition. In this context, it clear from Tables (5 and 6 ) that feed conversion ratio of G1, G2 and G3 were very close and recorded 27.04 $\mathrm{kg}, 27.9 \mathrm{~kg}$ and $27.73 \mathrm{~kg}$, respectively of dry matter intake to produce one $\mathrm{kg}$ of weaned lambs.

\section{Economical efficiency}

The attained economic indicators declared obviously the positive economic consequences of inclusion of Azzawi date in CFM when feeding Barki ewes. Results in Table (7) showed that, during the experimental period each ewe consumed close quantities of Alfalafa hay (as fed). On the other hand, 
G1 (control group) consumed lower amounts of CFM than the other two groups $(129.39 \mathrm{~kg}$ vs. $131.23 \mathrm{~kg}$ and $134.22 \mathrm{~kg}$, respectively). The results showed that, as the percentage of Azzawi date increased in CFM (from $0 \%$ up to $100 \%$ ), total feed costs per ewe decreased ( LE 527.59 vs. LE 485.49 and LE 447.32, respectively). Subsequently, relative reductions in total feed costs per ewe were $-7.98 \%$ and $-15.22 \%$, for G2 and G3, respectively in comparison with G1. In this context, economic indicators proved that although, G1 generated the highest revenues per ewe and recorded LE 582.2, yet, it was insufficient to compensate its related feed costs.

The current results revealed that, G3 achieved the lowest feed costs to produce one $\mathrm{kg}$ of lambs weaned and estimated as (LE 27.38), followed by G2 (LE 30.00), while G1 was the highest and reached LE 31.55. In the same time, it is of interest to observe that benefit/cost ratio improved due to incorporating of Azzawi date in CFM from 1.11 in case of G1 and achieved 1.28 in case of G3, which means that G3 is more profitable than $\mathrm{G} 1$ and $\mathrm{G} 2$.

Table 6. Dry matter intake (kg) per ewe over the experimental period

\begin{tabular}{lccc}
\hline Periods & G1 & G2 & G3 \\
\hline $\begin{array}{l}\text { Mid pregnancy period (77 days): } \\
\text { DMI/h/d }\end{array}$ & 0.865 & 0.865 & 0.865 \\
DMI/h/P & 66.605 & 66.605 & 66.605 \\
Late pregnancy and parturition: & & & 1.695 \\
$\quad$ DMI/h/d & 1.69 & 1.67 & 169.5 \\
$\quad$ DMI/h/P & 169 & 167 & 453.12 \\
Total dry matter intake/h & 452.24 & 452.24 & 27.73 \\
$\begin{array}{l}\text { Feed conversion rate, } \\
\text { (kg DM/kg gain of weaned lambs) }\end{array}$ & 27.04 & 27.90 & \\
\hline
\end{tabular}

$\mathrm{DMI} / \mathrm{h} / \mathrm{d}$; dry matter intake per ewe per day, DMI/h/p; dry matter intake per ewe per period

Table 7. Economic indicators of Barki ewes under different treatment groups

\begin{tabular}{lccc}
\hline Item & $\mathbf{G 1}$ & $\mathbf{G 2}$ & $\mathbf{G 3}$ \\
\hline $\begin{array}{l}\text { No. of animals } \\
\text { Total feed intake/h/p (as fed), kg: }\end{array} \quad 10$ & 10 & 10 \\
$\quad$ Concentrate feed mixture, kg & & 134.22 \\
$\quad$ Alflafa hay, kg & 129.391 & 131.23 & 134.45 \\
Feed costs/h/p: & 135.653 & 133.65 & 232.2 \\
$\quad$ Concentrate feed mixture, LE & & 213.84 \\
$\quad$ Alflafa hay, LE & 310.54 & 271.65 & 447.32 \\
Total feed costs /h/p, LE & 217.05 & 213.84 & -15.22 \\
Relative feed costs reduction, $\%$ & 527.59 & 485.49 & 27.38 \\
Feed costs / kg weaned, LE & ---- & -7.98 & 571.9 \\
Revenues/h, LE & 31.55 & 30.0 & 1.28 \\
Benefit/Cost ratio & 582.2 & 567.0 & 1.17 \\
\hline
\end{tabular}

G1; ewes fed a diet free of Azzawi date (Control), G2; ewes fed a diet contains 50\% Azzawi date, and G3; ewes fed a diet contains $100 \%$ Azzawi date. Prevailing market prices were applied to conduct economic indicators.

\section{CONCLUSION}

It could be concluded that, there is considerable opportunity for sheep producers to improve the economical returns by refining the feeding practices. The current study proved that, incorporation of Azzawi date instead of corn grain was appropriate as an energy source in CFM of Barki ewe's diet. Utilization of Azzawi date did not seem to improve ewe or lamb production traits. In the meantime, it had no adverse effects on biological performance. From the standpoint of feed costs of kilogram gain, it appears that, the proposed experimental diets were more profitable compared to the traditional ones.

\section{REFERENCES}

Abdel-Aziz, M.M., 1983. A study on the biological efficiency of meat production in Barki sheep. M. Sc. Thesis, Zagazig University, Zagazig, Egypt.
Ahmed, A.M., E.S.E. Galal and A.A. Younis, 1992. Estimates of productive and reproductive performances of commercial flock of Barki sheep. Egypt. J. Anim. Prod., 29: 109-122.

A.O.A.C., 2000. Official Methods of Analysis, $\left(16^{\text {th }}\right.$ edit.). Association of Official Analytical Chemists, AOAC, Arlington, VA, USA.

Ben Salem, H. and A. Nefzaoui, 2003. Feed blocks as alternative supplements for sheep and goats. Small Rum. Res. 49: 275-288.

Duncan, D.B., 1955. Multiple range and multiple F tests. Biometrics 11:1-42.

Gabina, D., 1989. Improvement of the reproductive performance of Rasa Aragonesa flocks in frequent lambing systems. II. Repeatability and heritability of sexual precocity, fertility and litter size. Selection strategies

Livest. Prod. Sci. 22 (1): 87-98.

Khattab, I., A. Abd-Elwahed and K. Kewan, 2012. The use of In Vitro gas production technique to predict the nutritive value of Azzawi date 
palm as a replacer for yellow corn grain in ruminant diets under Siwa Oasis conditions. Egypt. J. of Nut. and Feeds, National Research Council, 15 (1) (Special Issue), 169-178.

Mohammady, M.I., 1999. Biological efficiency of sheep and goat production. M.Sc. Thesis, Faculty of Agriculture, Cairo University.

Mohammady, M.I., I.M. Khattab, M.F. Shehata, A. Abd-Elwahed and K. Kewan., 2013. Growth performance, carcass traits and economic efficiency of Barki lambs fed Azzawi date. Egypt. J. of Anim. Prod., 45:57-67

NRC, 1985. Nutrient Requirements of Sheep. $6^{\text {th }}$ ed. National Academy of Sciences, Press Washington D.C. USA.
Rekik , M. N., H. Lassoued, M. Ben Salem and Mahouachi, 2008. Effects of incorporating wasted dates in the diet on reproductive traits and digestion of prolific D'Man ewes. Anim. Feed Sci. and Tech., 147: 193-205.

Robinson, J.J., 1983. Sheep Production, (Ed. W. Haresign): p.111, (Butterworths, London).

SAS, 2004. Statistical Analysis System. SAS statistics. Guide release, version 8.00 TS level OOMO, SAS Institute Inc., Cary, NC, USA.

Treacher, T.T., 1983. Sheep Production, (Ed. W. Haresign): p.133 (Butterworths, London).

Younis, A. A., M. M. Abdel Aziz, E. A. Afifi and M. Khaiery, 1984. Biological efficiency of meat production in Barki sheep. World Rev. of Anim. Prod., 4: 31-37.

\section{التقييم الحيوى والإقتصادى للنعاج البرقى المغذاة على علائق تحتوى على البلح العزاوى تحت الظروف الصحراوية فى

